\title{
Human papillomavirus: Its identikit and controversial role in oral oncogenesis, premalignant and malignant lesions (Review)
}

\author{
GIUSEPPINA CAMPISI ${ }^{1}$, VERA PANZARELLA ${ }^{1}$, MICHELE GIULIANI $^{2}$, CARLO LAJOLO $^{2}$, OLGA DI FEDE ${ }^{1}$, \\ SILVIA FALASCHINI ${ }^{4}$, CHIARA DI LIBERTO ${ }^{1}$, CRISPIAN SCULLY ${ }^{3}$ and LORENZO LO MUZIO ${ }^{4}$ \\ ${ }^{1}$ Department of Oral Sciences, University of Palermo, Palermo; ${ }^{2}$ Institute of Dental Surgery, \\ University Cattolica del Sacro Cuore, Rome, Italy; ${ }^{3}$ University College London, Eastman Dental Institute, \\ London, UK; ${ }^{4}$ Department of Surgical Sciences, University of Foggia, Foggia, Italy
}

Received October 3, 2006; Accepted December 1, 2006

\begin{abstract}
Human papillomaviruses (HPVs) are a group of host-specific DNA viruses, with a remarkable epithelial cell specificity: they have been reported principally in the anogenital tract, urethra, skin, larynx, tracheo-bronchial and oral mucosa. More than 100 different HPV types have been identified and classified as high (e.g. 16, 18, 31) or low (e.g. 11, 42, 36) -risk (HR and LR), based on their association with cervical carcinoma. The carcinogenic role of HR-HPV revolves mainly around two of its oncoproteins: HPV-E6 which promotes degradation of the p53 tumour suppressor gene product and HPV-E7 which modifies the $\mathrm{pRb}$ tumour suppressor gene product, inhibiting the activity of TGF-ß2. Since these viral oncoproteins are capable of transforming primary human keratinocytes from either genital or upper respiratory tract epithelia, they have been considered to play a role in disrupting cell-cycle regulatory pathways leading to a genetic progression to ano-genital cancer and, possibly, also to oral squamous cell carcinoma (OSCC). Recently, the oncogene HPV-E5 has also been found to transform cells by modulating growth factor receptors. On the basis of the high, although very variable, frequency of HR-HPV in OSCC, an oral malignant potential of HPV infection has been hypothesised but not definitively confirmed. Major aims of this review are to update the understanding of HPV activities with respect to oral oncology and to comment on the HPV DNA reported frequencies in OSCC and potentially malignant oral lesions. A computer database search was performed, through the use of MEDLINE (PubMED) and Cochrane Library, for the last three decades. Search key words used were: human
\end{abstract}

Correspondence to: Professor Lorenzo Lo Muzio, Department of Surgical Sciences, University of Foggia, Via Carelli 28, 71100 Foggia, Italy

E-mail: 1lomuzio@tin.it

Key words: human papillomavirus infection, oral mucosa, potentially malignant oral lesions, oral squamous cell carcinoma papillomavirus, HPV and cancer, HPV and oral lesions, HPV and oral premalignant lesions, HPV and oral cancer, HPV and HNSCC, HPV and oral mucosa. The search was of all fields, all languages and all dates available.

\section{Contents}

1. Human papillomavirus: identikit of a virus

2. HPV and oral oncology

3. Conclusions

\section{Human papillomavirus: identikit of a virus}

Structural characteristics and natural history of infection. HPVs belong to the new Papillomaviridae family and are an heterogeneous group of viral agents which infect epithelia, with an intra-nuclear mode of replication (1). HPVs have a small diameter $(50 \mu \mathrm{M})$ and a genome made of around $7200-8000$ base pairs (5.2x10 dalton molecular weight), covered by an iso-exahedric capsid without envelope and consisting of 72 capsomeres (2-4).

Capsid proteins are represented by a major capsid protein, L1 (of $~ 54.000$ daltons molecular weight), and a minor capsid protein, L2 (of 76.000 daltons molecular weight). The latter, unlike the major capsid protein, appears to be highly type-specific and can therefore be used as a target in the immunohistochemical typing of HPV infection $(5,6)$. The viral DNA guanine-cytosine content ranges between $42.6 \%$ and $50 \%$, i.e. very similar to that of human host cells, where the guanine-cytosine base content ranges between $42 \%$ and $43 \%$ (7).

Molecular biology techniques have facilitated the characterization of the entire HPV genome, where three different functional regions are identified, as a profile of their gene expression. The first region (Early or ' $E$ ' region) extends for approximately $45 \%$ of the genome and codifies earlyfunctional proteins. The second region (Late or 'L') extends for approximately $40 \%$ of the viral DNA and codifies latestructural proteins. The third region (Long Control Region or 
Table I. HPV genoma and functions of codified proteins.

\begin{tabular}{ll}
\hline Proteins & \multicolumn{1}{c}{ Function } \\
\hline pE1 & Initiating DNA replication and transcription \\
pE2 & Controlling DNA replication and transcription (ORFs E6-E7) \\
pE3-pE8 & Not still clear \\
pE4 & Disrupting the cytoskeleton \\
pE5 & Interacting with cellular proteins (EGFR) \\
pE6 & Degrading p53 \\
pE7 & Binding Rb proteins \\
pL1 & Capsid major structural protein \\
PL2 & Capsid minor structural protein \\
\hline
\end{tabular}

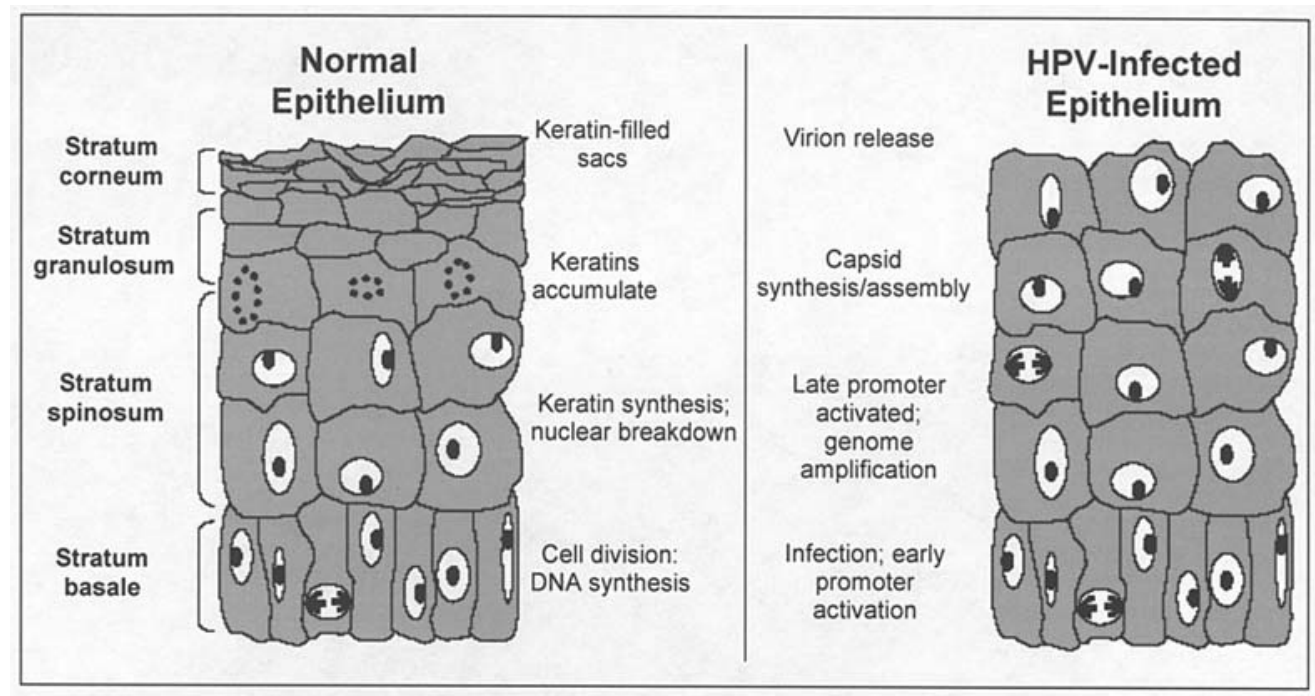

Figure 1. HPV infection in relation to keratinocyte level of differentiation (modified by Longworth)

'LCR'), contains sequences regulating gene transcription, and performs exclusively regulatory functions (8) (Table I). The two first codifying regions contain nucleotide sequences defined as 'Open Reading Frames' (ORFs), with the potential for transcription of specific mRNA (9).

HPV types. From the phylogenetic point of view, HPVs are classified according to the level of homology existing among nucleotide sequences in the genomic regions (i.e. E6, $\mathrm{E} 7$ and L1). If the homology with respect to existing types is $<90 \%$ the HPV is classified as a new type; if homology is 90 $98 \%$ it is classified as a sub-type; if homology is $\geq 98 \%$ it is classified as a variant $(6,10,11)$.

Thus far, more than 100 different genotypes of HPV have been isolated, by means of molecular cloning in plasmids or bacteriophages, sequenced and are available in the HPV database (http//:hpv-lanl.web.gov).

$H P V$ infection. HPVs are mostly transmitted by close contact, especially sexually but vertical spread (passage through the uterine canal during delivery) and self-inoculation are also recognised routes of infection (12-16).
After HPV inoculation, three mechanisms of infection can manifest: i) Plasmid replication, which occurs in the cells of lower epithelium and may in turn subdivide into two phases; a) amplification of viral DNA up to 50 to 400 couples/diploid genoma, and b) maintenance of a constant number of couples for several cell generations. ii) Vegetative replication, which occurs in cells that differentiate from the epithelium and involves a link between cell differentiation and viral expression of the gene. iii) Productive replication, in which the virus is expelled from the epithelial cells when they undergo desquamation and is transmitted by direct contact (especially genital warts), or by indirect contact.

HPVs are characterized by a special trophism for squamous epithelial cells, keratinocytes. The synthesis of viral DNA and the expression of viral genes (especially for those codifying capsid proteins) are linked to the keratinocyte level of differentiation (Fig. 1). The normal viral replication cycle is a highly regulated process, depending both on some viral proteins codified by the viral genome and the degree of differentiation of the infected cell. Infection usually starts in the basal and 
para-basal cells of squamous epithelium. The changes in keratinocytes from the basal layer to the surface of the epithelium, provide a suitable micro-environment for productive cell replication, responsible for the transformation of the keratinocyte into a permissive cell (17).

To activate infection, the virus must have access to the 'generative' compartment of the epithelium through the exposure of superficial layers to reach the basal layer where the specific $\alpha 6$ integrin receptor is present (18). Then, during the initial phase of infection, when the virus colonizes basal and para-basal cells of the epithelium, the viral genome undergoes episomal replication, since it is present as an extra-chromosomal fragment of circular DNA. At this stage of episomal or early replication, relatively few copies of viral DNA (20-200) per host cell are present. The episomal form acts as a reservoir of infected cells, which are morphologically indistinguishable from non-infected cells, and is responsible for the latent status of infection.

When the infection becomes productive, the viral genes are expressed sequentially from early genes to late genes, following the epithelial squamous differentiation, starting from basal and para-basal cells, where early portions of the viral genoma are more active and proceeding to higher epithelial layers (both the intermediate and the superficial) along with the formation of the complete virion (i.e. the infecting viral particle) (19). The classic viral cytopathic effects may then appear: koilocytosis in particular, is considered as the evident expression of a viral cytopathic effect. The koilocytic cell shows a thicker cytoplasm at the level of the cell internal membrane wall and an atypical morphologically collapsed and stellate nucleus $(20,21)$. Histologically, HPV infection may then appear as acanthosis, dyskeratosis, keratinocyte multinucleation and koilocytosis.

Immune responses play an important role in HPV infections. It is well documented that, in immunocompetent subjects, skin warts often regress spontaneously whereas, in immune deficiency, a higher incidence and persistence of skin and mucosal infections induced by HPV are found (22). Nevertheless, in HPV-related diseases in immunocompetent hosts, immune responses are generally poorly expressed, as compared to those seen in other viral infections, presumably because the HPV replication cycle takes place inside maturing keratinocytes which are able to continuously remove mature virions, and HPV thus tends to cause cell proliferation rather than cell lysis (23). As a result, during HPV infection, the local or systemic viral antigen presentation to the immune system by antigen-presenting cells (APC), is minimal and thus infection often persists for months or even years (24), albeit without necessarily being recognised clinically. Absence of clinically detectable lesions is not, therefore, synonymous with absence of HPV infection.

Molecular and oncological aspects. Based on their relationship with cervical cancer, HPVs, have been divided into two groups: those at 'high risk' (HR-HPV: 16-18-31-33-35) associated with potentially and overtly malignant lesions and those at 'low risk' (LR-HPV: 6-11-13-32), more commonly associated with benign diseases $(18,25,26)$.

HPV genes. The HPV genome contains 10 genes, 3 of which have potential transforming action (E5, E6, E7). In

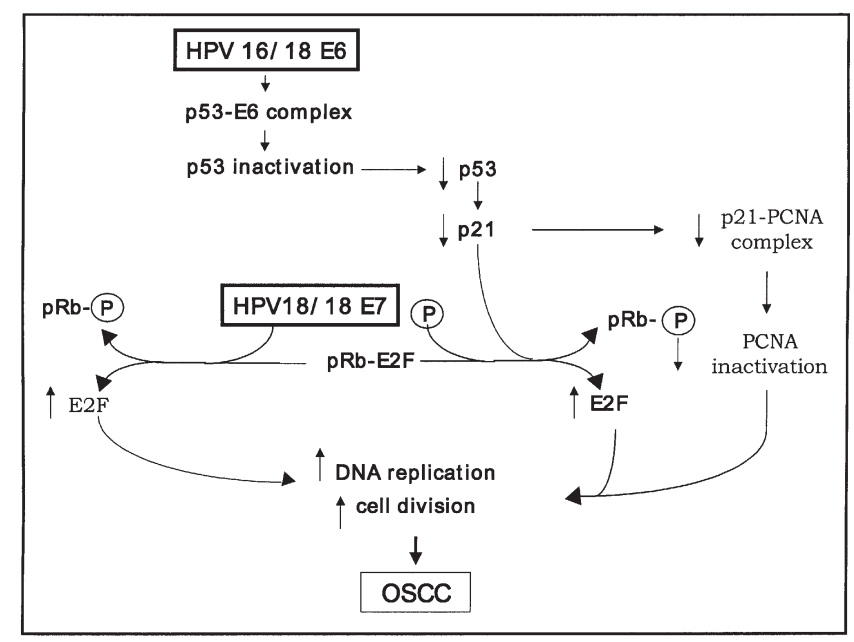

Figure 2. Unregulation of cellular mechanisms mediated by E6 and E7 HPV DNA segments.

synthesis, the initial viral infection factor is $\mathrm{pE} 1$ which binds to a genomic region rich in adenine and thymine and codifies for factors directly involved in plasmid replication. The other protein needed for replication is $\mathrm{pE} 2$, a polypeptide with trans-activating function, that binds DNA in the ACCNGGGT sequence, common to all papilloma viruses. The E5 region codifies for a $7-\mathrm{kD}$ protein that, alone, can cause stable alterations in cell growth and morphology. Expression of the E6 and E7 genes mediates the blockade of cell differentiation and cell immortalization respectively, by codifying oncoproteins pE6 and pE7, forming complexes with the p53 and $\mathrm{p} 105 \mathrm{Rb}$ tumor suppressor gene products respectively, inhibiting their function as down-regulators in cell replication (27). HPV integration occurs through the viral episomal DNA rupture, in correspondence with E2 and E1 ORFs, with preservation of E6 and E7 segments that may therefore undergo transcription (28), causing a disturbance in cell control mechanisms and an increased proliferation of infected cells.

The consequence is unregulated cellular replication with an increased risk of chromosomal aberrations and excessive production of viral proteins interacting with cellular proteins $(29,30)$ (Fig. 2).

HPV identification. HPV is not cultivable and, since direct investigation by electronmicroscopy or immunological analysis are not especially useful (antigenic viral components are not always present in the infected tissues), and histopathology is only suggestive, definitive diagnosis of HPV infection is now by molecular biology methods (e.g. techniques of amplification and/or hybridisation). The techniques of Southern blotting (SB) and In situ hybridization (ISH) have been used extensively in the past to identify viral sequences in tissues. SB requires the isolation and purification of cellular DNA from a specimen, and the DNA is then digested into fragments by restriction enzymes; the fragments are separated by size; immobilized on filters; and then probed with radiolabeled or chemiilluminescent probes specific for a given HPV type. ISH does not require DNA isolation from tissue but rather the tissue or smear is probed directly for the presence of viral sequences (8). 
Table II. Literature review of HPV prevalence in potentially malignant lesions.

\begin{tabular}{|c|c|c|c|c|}
\hline $\begin{array}{l}\text { Molecular investigation } \\
\text { techniques }\end{array}$ & Oral lesions & $\mathrm{HPV}^{+}$ & $\%$ & Studies \\
\hline SB & Leucoplakia & $4 / 5$ & 80 & Löning et al, 1985 (70) \\
\hline SB & Dysplasia/hyperplasia/lichen planus & $16 / 21$ & 28.6 & Maitland et al, 1987 (37) \\
\hline ISH & Dysplasia & $21 / 202$ & 10.4 & Gassenmaier and Hornstein, 1988 (62) \\
\hline ISH & Dysplasia & $6 / 22$ & 27.3 & Syrjanen et al, 1988 (19) \\
\hline ISH & Leucoplakia & $0 / 10$ & 0 & Shroyer and Greer, 1991 (72) \\
\hline SB & Leucoplakia & $3 / 3$ & 100 & Cox et al, 1993 (79) \\
\hline ISH & Leucoplakia & $5 / 13$ & 38.5 & Gonzàles-Moles et al, 1998 (83) \\
\hline PCR & Leucoplakia & $5 / 5$ & 100 & Balaram et al, 1995 (99) \\
\hline PCR & Dysplasia & $0 / 3$ & 0 & Fouret et al, 1995 (59) \\
\hline PCR & Leucoplakia & $9 / 21$ & 42.9 & Palefsky et al, 1995 (65) \\
\hline PCR & Hyperplasia/dysplasia & $29 / 34$ & 85.2 & Bouda et al, 2000 (60) \\
\hline PCR & Dysplasia & $31 / 51$ & 60.8 & Sugiyama et al, 2003 (42) \\
\hline PCR & Leucoplakia/lichen planus & $26 / 139$ & 18.7 & Campisi et al, 2004 (33) \\
\hline
\end{tabular}

More recently, polymerase chain reaction (PCR) has been recognised as the most appropriate method to identify and type the HPV genome (31) because of higher sensitivity and specificity. For example, studies on head and neck squamous cell carcinoma (HNSCC) using PCR show an average HPV positivity of $34.5 \%$ compared with $24.5 \%$ by SB (8). In a PCR reaction, the target sequence of viral DNA is denatured and hybridised with two small complementary genomic sequences (primers) which permit Taq polymerase-enzyme to bind to it and to duplicate the target DNA sequence. This series of reactions (denaturation, hybridisation of primers and polymerization of Taq) is then reproduced 30-40 times to hugely amplify the target DNA sequence that is then identified by other methods (e.g. migration on agarose-gel, hybridisation by specific probes).

\section{HPV and oral oncology}

LR-HPV (i.e. HPV types $2,4,11,13,32$ ) are responsible for benign skin and mucosal lesions (ordinary warts, condylomas, focal epithelial hyperplasia, squamous cell papillomas, Bowen's papillomatosis), whilst HR-HPV (i.e. 16, 18, 31, 33, $35,58)$ are related to potentially or explicitly malignant lesions (cervical intra-epithelial neoplasms, cervical, penile and vulvar carcinomas, giant condylomas of Bruschke and Lowenstein) (26,32-36). However, both kinds of HPV are sometimes recognised in clinically apparently healthy oral mucosa (37-43) and the significance of this, if any, is unclear.

A key role for HPV has been confirmed in genital neoplastic disease: $80-90 \%$ of uterine cervix and ano-genital carcinomas show HPV infection $(8,18,44,45)$ and numerous epidemiological investigations support a relationship (46-53).
The hypothesis of a role for HPV in HNSCC and in the onset of oral squamous cell carcinomas (OSCC) (54), is supported by the observation that oral mucosa has similar histological features and properties as vaginal mucosa (55) and that the virus is able to immortalize human keratinocytes in vitro (45,56-58).

HPV and potentially malignant oral lesions. HPV DNA prevalence, in oral potentially malignant lesions (PML) ranges from $0 \%$ to $85 \%(59,60)$ with a higher prevalence of HPV 16 or 18 genotypes (61-65). Such a wide variation is probably due to demographic variables, different categorization standards of lesions investigated (sometimes not supported by histology) and, above all, to different sampling techniques (biopsies, mouth rinsing or brushing) and different imaging techniques, from the less sensitive ISH to the highly sensitive 'nested' PCR (34) (Table II).

In order to understand the more recent findings on HPV infection in PML, we therefore analysed only the results from those studies investigating HPV infection in lesions clearly described from both clinical and histological viewpoints. Following data abstraction, the most well-defined PML that have been studied in relation to HPV infection are: oral leucoplakia (OL) and oral lichen planus (OLP) $(66,67)$.

Oral leucoplakia was defined as a white patch or plaque, clinically and pathologically unrelated to any other disease (Fig. 3a). From the viewpoint of aetiology, OL can be distinguished into OL correlated with the use of tobacco, and idiopathic OL, as showing a higher risk to progress to malignancies (68).

An aetiological role for HPV in OL was initially suggested from light microscopy studies (69), and supported by the 


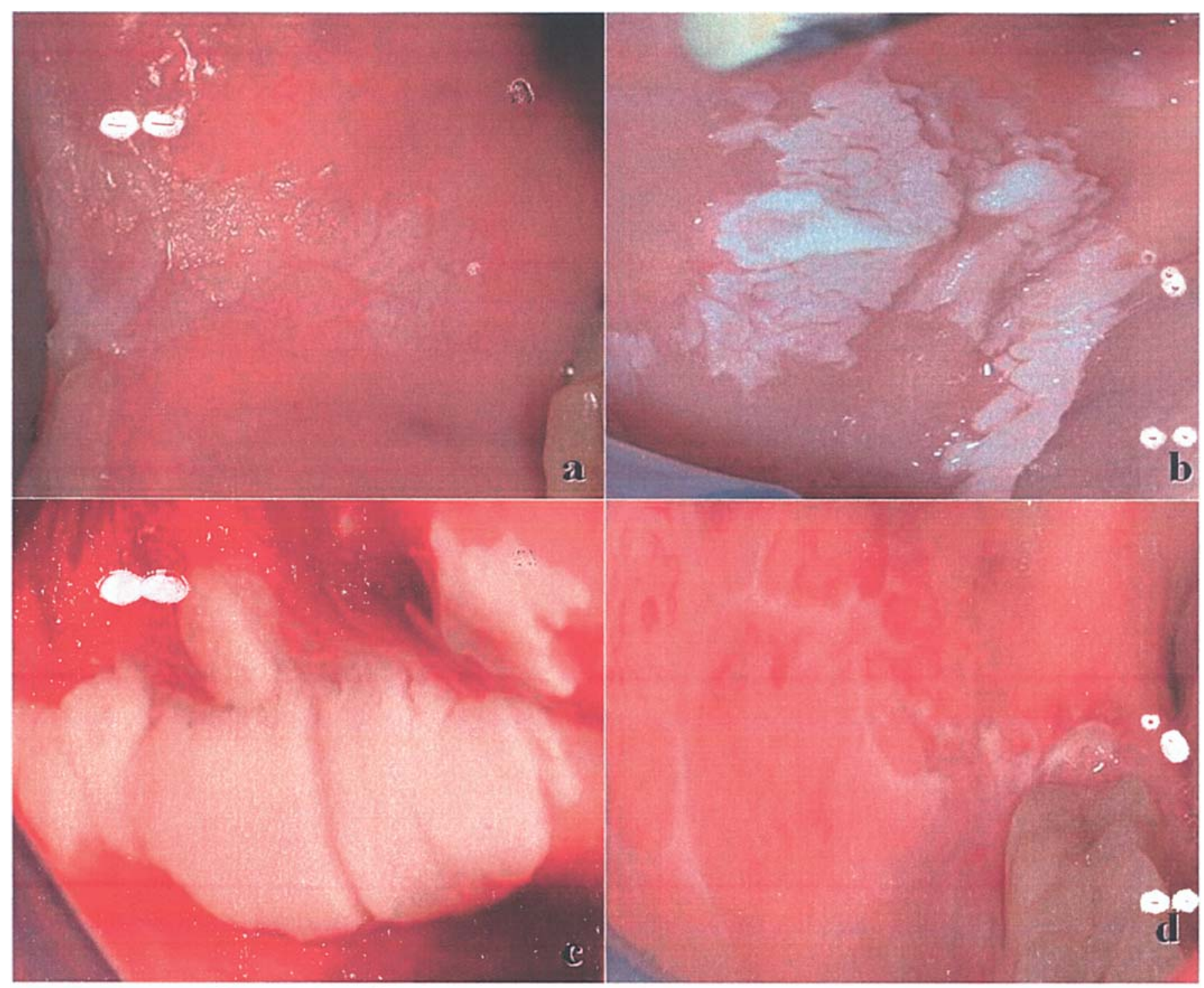

Figure 3. (a) Homogeneous leucoplakia, (b and c) proliferative verroucous leucoplakias, and (d) reticular oral lichen planus.

identification of HPV antigens (70) and then HPV-DNA $(37,71)$. However, data are controversial with respect to the prevalence of HPV infection. Miller and White (39), in a review of studies using ISH to identify HPV in benign OL (i.e. without dysplasia), reported a prevalence ranging from $0 \%$ to $80 \%$, significantly greater in fresh and frozen specimens $(43.1 \%)$ than in paraffin-embedded tissues $(12.2 \%)$. However, in OL with dysplasia and using PCR for HPV-DNA detection, the prevalence ranged from $17 \%$ (72) up to $68.6 \%$ (42). Moreover, if Uppsala criteria are considered (73) and the proliferative verrucous form of leucoplakia (proliferative verrucous leucoplakia or PVL) is excluded from the analysis, the overall HPV prevalence in other OL dropped to $17.6 \%$ (in paraffin-embedded biopsies from non-dysplastic and dysplastic lesions) (33).

Campisi et al, examined the relationship in OL between HPV and some molecular predictors of malignant progression such as apoptosis markers (bcl-2 and survivin) and proliferation markers (proliferating cell nuclear antigen; PCNA). The risk of HR-HPV infection was found to be independently associated with survivin and PCNA expression, suggesting that these markers could be involved in HPV-mediated disorders of epithelial maturation (74).

PVL is the form of OL thought to have the strongest relationship to HPV infection. This clinical disorder is a rare and particularly aggressive form of exophytic leucoplakia, with a high potential for malignant transformation (Fig. 3b and c) (75), with a $90 \%$ malignant evolution to carcinoma in situ (65), regional lymph-nodal involvement and distant metastases (76), and is highly resistant to treatment. Malignant transformation of PVL has been primarily found in elderly non-smoking women with a history of successive biopsies in long-standing leucoplakia (77). The aetiology of PVL does not seem to involve cigarette smoking or Candida spp infection, as suggested by Silverman and Gorsky (76). The association of PVL and HPV (especially genotype 16) has been supported by several reports $(65,76,78)$, although with a wide range from $10 \%$ to $85 \%$, of HPV infection $(65,78)$ (Table III). However, a multi-centre study recently reported no statistically significant difference, in terms of HPV-DNA detection, 
Table III. Literature review on HPV prevalence in PVL.

\begin{tabular}{lccc}
\hline Studies & Cases & HPV $^{+}$n $(\%)$ & Mode of detection \\
\hline Palefsky et al, $1995(65)$ & 9 & $7(89.0)$ & PCR \\
Silverman et al, $1997(76)$ & 54 & $38(70.3)$ & PCR \\
Fettig et al, 2000 (78) & 10 & $1(10.0)$ & PCR \\
Sugiyama et al, $2003(42)$ & 51 & $31(61.0)$ & PCR \\
Campisi et al, $2004(33)$ & 58 & $14(24.1)$ & PCR \\
\hline
\end{tabular}

Table IV. Literature review on HPV prevalence in OSCC according to molecular investigation techniques.

\begin{tabular}{|c|c|c|c|c|}
\hline Molecular investigation techniques & Cases & $\mathrm{HPV}^{+}$ & $\%$ & Studies \\
\hline SB & 6 & 3 & 50 & Löning et al, 1985 (70) \\
\hline SB & 15 & 7 & 46.7 & Maitland et al, 1987 (37) \\
\hline ISH & 68 & 16 & 23.5 & Gassenmaier and Hornstein, 1988 (62) \\
\hline SB & 26 & 5 & 19.2 & Kashima et al, 1990 (71) \\
\hline SB & 8 & 4 & 50 & Cox et al, $1993(79)$ \\
\hline PCR & 26 & 16 & 61.5 & Ostwald et al, 1994 (44) \\
\hline PCR & 91 & 67 & 73.6 & Balaram et al, 1995 (99) \\
\hline PCR & 21 & 2 & 9.5 & Fouret et al, 1995 (59) \\
\hline PCR & 71 & 10 & 14.1 & Paz et al, 1997 (102) \\
\hline PCR & 193 & 22 & 11.4 & Schwartz et al, 1998 (111) \\
\hline PCR & 19 & 17 & 89.5 & Bouda et al, $2000(60)$ \\
\hline $\mathrm{PCR} / \mathrm{SB} / \mathrm{ISH}$ & 84 & 10 & 11.9 & Gillison et al, 2000 (119) \\
\hline PCR & 41 & 2 & 4.9 & Ringstrom et al, 2002 (118) \\
\hline PCR & 13 & 8 & 61.5 & Giovannelli et al, 2002 (110) \\
\hline PCR & 94 & 10 & 10.6 & Ritchie et al, 2003 (114) \\
\hline PCR & 86 & 30 & 34.9 & Sugiyama et al, 2003 (42) \\
\hline PCR & 16 & 8 & 50 & Correnti et al, 2004 (122) \\
\hline PCR & 29 & 3 & 10.3 & Sridhar et al, 2003 (103) \\
\hline PCR & 93 & 8 & 8.6 & Smith et al, 2004 (109) \\
\hline PCR & 18 & 9 & 50 & Lo Muzio et al, 2005 (110) \\
\hline PCR & 63 & 24 & 38.1 & Campisi et al, 2006 (124) \\
\hline
\end{tabular}

between PVL $(24.1 \%)$ and common OL (25.5\%), nor any special role for HPV in PVL onset (33). This controversy remains to be resolved.

Oral lichen planus is a chronic inflammatory disease of unknown aetiology and immune pathogenesis, with a small malignant potential (Fig. 3d). Information on HPV infection in OLP is scanty, but the few studies published report a high frequency $(37,79)$ from $27.3 \%$ (80), to $42.0 \%$ (81) or even $65.0 \%$ (82). Both Gonzales-Moles (83) and Jontell et al (82) observed that only the erosive variant of OLP was found to be HPV positive but this was not confirmed in another study (33). There is agreement between several authors $(34,84)$ on the prevalence of HPV sub-type 18, as indicative of a peculiar geographic genotypic pattern of HPV (33).

Oral cancer and $H P V$. Extrinsic factors primarily responsible for the onset and evolution of OSCC include UV rays, tobacco and alcohol, especially if coexistent $(85-89,90)$. In some 
cases, trauma $(86,91)$, poor oral hygiene (92-95), or Vitamin A, B and C deficits $(96,97)$, may be implicated. However, many cases have none of these identifiable risk factors.

Miller and Johnstone (18), in a meta-analysis of OSCC, observed that HPV may be a significant and independent risk factor. The prevalence of HPV in HNSCC and OSCC varies, depending on variations in several parameters considered: ethnic and geographic differences in population, type of specimen (biopsies, scrapes), selection of preparation method (fresh frozen or fixed), use of HPV detection methods with different sensitivity levels (SB, ISH, PCR) and, especially, the different type of HNSCC examined. Although early data reported an HPV prevalence in OSCC ranging between $20 \%$ and $30 \%(39,98)$, numerous other studies have reported HPVDNA in $50 \%$ of cases $(44,64,99,100)$. In agreement with Ha and Califano (101), we have suspected a misestimating of these latter data of HPV prevalence, attributed mostly to the different identification methods used (Table IV).

It is also clear that HPV is more frequently detected in cancer of Waldeyer's tonsillar ring $(102,103)$, thanks to the easier viral access to basal mucosal cells of the tonsillar crypts (104) than in cancer elsewhere in the mouth. However, few studies have been based on a correct distinction between cancers at oral and oropharyngeal sites, as recommended by the American Joint Committee on Cancer (AJCC) (105). For this reason, Herrero et al (103) and, later, Kreimer et al (106) hypothesized that, although there is a proven association between HPV and oropharyngeal tumours, the misclassification of some HPV-positive oropharyngeal cancers as OSCC, could partly explain the HPV-positivity of some 'oral' cancers.

Other authors hypothesise that the carcinogenic potential of HPV might be attributed to the concomitant action of several risk habits (i.e. tobacco smoking and alcohol drinking) and genetic factors (107). Consistently to this theory, Schwartz et al (111) reported a potential interaction effect with HPV expression only in current smokers. On the contrary, Hafcamp et al (108) showed a significant correlation between HPV integration and reduced or absent exposure to the known risk factors of HNSCC/OSCC. Smith et al (109) and Lo Muzio et al (110) demonstrated a statistically significant association between HPV infection and alcohol consumption but not with tobacco use, as being found to be even inversely related to HPV infection. In India, HPV DNA was detected less frequently in tumour specimens from tobacco chewers than in those from non-chewers (103). The theory that non-tobacco users are more likely than tobacco users to have HPV-related tumours could be explained by the evidence that alcohol acts as a permeability enhancer of oral mucosa altering the mucosal structure and thereby aiding penetration of HPV through the epithelial layers (110); whereas tobacco using promotes epithelial keratosis as inhibiting viral infiltration and maturation (103).

Some studies report, on an epidemiological and/or molecular basis, a significant association between HPV 16-18 infection and OSCC $(42,43,113,114)$. Kreimer et al $(106)$, in a recent systematic review of the literature, found HPV 16 and 18 to be the most common subtypes in HNSCC, respectively present in $16.0 \%$ and $3.9 \%$ of 2642 cases reviewed. These HPV subtypes are HR-HPV and able to transform both cervical and upper aero-digestive tract epithelia via expression of the viral oncoproteins E6 and E7 and the following de- regulation of cell cycle and apoptotic pathways, by inhibiting respectively, the activity of the cellular p53 and Rb tumour suppressor proteins $(115,116)$. HPV E6 and/or E7 transcripts and/or viral integration have been detected more frequently in OSCC containing HR-HPV (16, 18 and 33) (103).

In the light of these findings, it has been suggested that HPV detection, plus the expression of E6 and E7 are important prerequisites for HPV-dependent inactivation of p53 and Rb and important indicators of HPV involvement in oral carcinogenesis. In particular, Dai et al (115), in their recent AIRC multi-center study on the relationship between HPV 16 infection and TP53 mutation in oral cancer, conclude that it is not sufficient to find HPV-DNA in cancer specimens, but that some markers of E6 expression must also be identified, such as the presence of HPV 16 E6 antibodies or, as suggested by Akerman et al (117), increasing mRNA levels of epidermal growth factor receptor (EGFR).

One field recently investigated by Lo Muzio et al is the assessment of the type of relationship between HPV infection and cell cycle markers involved in the proliferation pathway and in the regulation of apoptosis. These authors found a negative association between HPV and PCNA, MIB-1 and survivin expression: indices of proliferative activity (PCNA and MIB-1 expression) were higher in HPV-negative cases (respectively $88.0 \%$ and $77.0 \%$ ) than in HPV-positive cases (respectively $66.0 \%$ and $44.0 \%$ ); similarly, survivin expression (an index of apoptosis blockage), was higher in HPV-negative cases $(100.0 \%)$, than in HPV-positive cases $(44.0 \%)$ with the maximum protective effect in HPV-positive smokers (110). Ringstrom et al reported a 5\% mortality in HPV-16-positive OSCC vs $31 \%$ in an HPV-negative group (118), findings which, although suggesting a favourable prognostic value of infection, are yet to be explained.

Studies which have tried to define a carcinogenic role for HPV by examining viral infection in relation to conventional OSCC determination parameters, such as histological grading (G1-2-3) and TNM staging have found a significant correlation between HPV infection and poorly differentiated (G3) HNSCC, showing, at the same time, a better prognosis for those found to be positive to infection $(42,114,119)$. Other authors, on the contrary, have failed to show any significant correlation between HPV-positive oropharyngeal carcinomas and their histological differentiation $(43,118,120)$; whereas Hilga et al (121) observed such correlation in well-differentiated (G1) and Correnti et al (122) in moderately differentiated carcinomas (G2). As regards TNM staging, Schwartz and Yueth (123) have observed HPV more frequently in stage II and III OSCCs, while Smith et al (109) observed HPV in advanced stage HNSCC, characterized by lymph node involvement. Finally, Campisi et al, have recently shown that HPV infection, if simultaneously correlated with histological grading and TNM staging, seems to prevail in intermediate stage lesions (II/T2), but without any specific histological degree. In other words, evidence relating HPV infection and histological grading of OSCC appears equivocal (124).

\section{Conclusions}

Risk factors primarily responsible for OSCC include UV rays, tobacco and alcohol, but many cases have none of these 
identifiable risk factors. HR-HPV is able to transform epithelia via expression of the viral oncoproteins E6 and E7 causing deregulation of cell cycle and apoptotic pathways, by inhibiting respectively, the activity of the cellular p53 and Rb tumour suppressor proteins. On the basis of the high frequency of HR-HPV in some types of OSCC, an oral malignant potential of HPV infection in oropharyngeal carcinoma is likely. The precise role of HPV in oral PML and in other forms of OSCC remains to be elucidated.

\section{References}

1. van Regenmortel MHV FC, Bishop DHL, Carstens E, Estes M, Lemon S, Maniloff J, Mayo MA, McGeoch D, Pringle CR and Wickner RB (eds): Virus Taxonomy. Seventh Report of the International Committee on Taxonomy of Viruses. Academic Press, New York, San Diego, 2000.

2. Howley PM: Role of the human papillomaviruses in human cancer. Cancer Res 51: 5019s-5022s, 1991.

3. Reid R and Campion MJ: The biology and significance of human papillomavirus infections in the genital tract. Yale J Biol Med 61: 307-325, 1988.

4. Cobb MW: Human papillomavirus infection. J Am Acad Dermatol 22: 547-566, 1990.

5. Pfister H: Biology and biochemistry of papillomaviruses. Rev Physiol Biochem Pharmacol 99: 111-181, 1984.

6. Pfister HFP: Papillomaviruses: particles, genome organization and proteins. In: Papillomaviruses and Human Disease. Syrjanen KJ, Gismann L and Koss LG (ed). Springer-Verlag, Heidelberg, pp1-18, 1987

7. Chow VT and Leong PW: Complete nucleotide sequence, genomic organization and phylogenetic analysis of a novel genital human papillomavirus type, HLT7474-S. J Gen Virol 80: 2923-2929, 1999.

8. McKaig RG, Baric RS and Olshan AF: Human papillomavirus and head and neck cancer: epidemiology and molecular biology. Head Neck 20: 250-265, 1998.

9. Boshart M, Gissmann L, Ikenberg H, Kleinheinz A, Scheurlen W and zur Hausen H: A new type of papillomavirus DNA, its presence in genital cancer biopsies and in cell lines derived from cervical cancer. EMBO J 3: 1151-1157, 1984.

10. Chang F, Syrjanen S, Kellokoski J and Syrjanen K: Human papillomavirus (HPV) infections and their associations with oral disease. J Oral Pathol Med 20: 305-317, 1991.

11. Pfister H, Krubke J, Dietrich W, Iftner T and Fuchs PG: Classification of the papillomaviruses - mapping the genome. Ciba Found Symp 120: 3-22, 1986.

12. Arena S, Marconi M, Ubertosi M, Frega A, Arena G and Villani C: HPV and pregnancy: diagnostic methods, transmission and evolution. Minerva Ginecol 54: 225-237, 2002.

13. Cason J, Kaye J, Pakarian F, Raju KS and Best JM: HPV-16 transmission. Lancet 345: 197-198, 1995.

14. Giles S: Transmission of HPV. Cmaj 168: 1391; author reply $1391,2003$.

15. Mindel A and Tideman R: HPV transmission - still feeling the way. Lancet 354: 2097-2098, 1999.

16. Rintala MA, Grenman SE, Puranen MH, Isolauri E, Ekblad U, Kero PO and Syrjanen SM: Transmission of high-risk human papillomavirus (HPV) between parents and infant: a prospective study of HPV in families in Finland. J Clin Microbiol 43: 376-381, 2005.

17. Femiano F: Papilloma virus. Review of the literature. Note II. Diagnosis and treatment. Minerva Stomatol 49: 179-186, 2000.

18. Miller CS and Johnstone BM: Human papillomavirus as a risk factor for oral squamous cell carcinoma: a meta-analysis, 19821997. Oral Surg Oral Med Oral Pathol Oral Radiol Endod 91: 622-635, 2001.

19. Syrjanen K, Mantyjarvi R, Saarikoski S, Vayrynen M, Syrjanen S, Parkkinen S, Yliskoski M, Saastamoinen J and Castren O: Factors associated with progression of cervical human papillomavirus (HPV) infections into carcinoma in situ during a long-term prospective follow-up. Br J Obstet Gynaecol 95: 1096-1102, 1988.

20. Santoro V, Pozzuoli ML and Colella G: Role of human papilloma virus in precancerous and cancerous lesions of the oral cavity. Review of the literature. Minerva Stomatol 46: 595-601, 1997.
21. Fornatora ML, Jones AC, Kerpel S and Freedman PD: It's time to modernize our approach to oral HPV lesions. Oral Surg Oral Med Oral Pathol Oral Radiol Endod 91: 494-496, 2001.

22. Chang F: Role of papillomaviruses. J Clin Pathol 43: 269-276, 1990.

23. Tindle RW and Frazer IH: Immune response to human papillomaviruses and the prospects for human papillomavirus-specific immunisation. Curr Top Microbiol Immunol 186: 217-253, 1994

24. Majewski S and Jablonska S: Immunology of HPV infection and HPV-associated tumors. Int J Dermatol 37: 81-95, 1998.

25. Badaracco G, Venuti A, Morello R, Muller A and Marcante ML: Human papillomavirus in head and neck carcinomas: prevalence, physical status and relationship with clinical/pathological parameters. Anticancer Res 20: 1301-1305, 2000.

26. Pillai MR, Phanidhara A, Kesari AL, Nair P and Nair MK: Cellular manifestations of human papillomavirus infection in the oral mucosa. J Surg Oncol 71: 10-15, 1999.

27. de Villiers EM: Papillomavirus and HPV typing. Clin Dermatol 15: 199-206, 1997.

28. Pfister H: Human papillomaviruses and skin cancer. Semin Cancer Biol 3: 263-271, 1992.

29. Munger K, Werness BA, Dyson N, Phelps WC, Harlow E and Howley PM: Complex formation of human papillomavirus E7 proteins with the retinoblastoma tumor suppressor gene product. EMBO J 8: 4099-4105, 1989.

30. Werness BA, Levine AJ and Howley PM: Association of human papillomavirus types 16 and 18 E6 proteins with p53. Science 248: 76-79, 1990.

31. Giovannelli L, Lama A, Capra G, Giordano V, Arico P, Ammatuna P, Giambelluca D, Mancuso S, Rubino E, Colletti P, Mazzola G, Belfiore P and Lima R: Detection of human papillomavirus DNA in cervical samples: analysis of the new PGMY-PCR compared to the hybrid capture II and MY-PCR assays and a two-step nested PCR assay . J Clin Microbiol 42: 3861-3864, 2004.

32. Pillai MR and Nair MK: Development of a condemned mucosa syndrome and pathogenesis of human papillomavirus-associated upper aerodigestive tract and uterine cervical tumors. Exp Mol Pathol 69: 233-241, 2000.

33. Campisi G, Giovannelli L, Arico P, Lama A, Di Liberto C, Ammatuna P and D'Angelo M: HPV DNA in clinically different variants of oral leukoplakia and lichen planus. Oral Surg Oral Med Oral Pathol Oral Radiol Endod 98: 705-711, 2004.

34. Giovannelli L, Campisi G, Lama A, Giambalvo O, Osborn J, Margiotta V and Ammatuna P: Human papillomavirus DNA in oral mucosal lesions. J Infect Dis 185: 833-836, 2002.

35. Burd EM: Human papillomavirus and cervical cancer. Clin Microbiol Rev 16: 1-17, 2003.

36. Kuffer R and Lombardi T: Premalignant lesions of the oral mucosa. A discussion about the place of oral intraepithelial neoplasia (OIN). Oral Oncol 38: 125-130, 2002.

37. Maitland NJ, Cox MF, Lynas C, Prime SS, Meanwell CA and Scully C: Detection of human papillomavirus DNA in biopsies of human oral tissue. Br J Cancer 56: 245-250, 1987.

38. Rose S, Lawton B, Brown S, Goodyear-Smith F and Arroll B: High rates of chlamydia in patients referred for termination of pregnancy: treatment, contact tracing, and implications for screening. N Z Med J 118: U1348, 2005.

39. Miller CS and White DK: Human papillomavirus expression in oral mucosa, premalignant conditions, and squamous cell carcinoma: a retrospective review of the literature. Oral Surg Oral Med Oral Pathol Oral Radiol Endod 82: 57-68, 1996.

40. Terai M, Hashimoto K, Yoda K and Sata T: High prevalence of human papillomaviruses in the normal oral cavity of adults. Oral Microbiol Immunol 14: 201-205, 1999.

41. Summersgill KF, Smith EM, Levy BT, Allen JM, Haugen TH and Turek LP: Human papillomavirus in the oral cavities of children and adolescents. Oral Surg Oral Med Oral Pathol Oral Radiol Endod 91: 62-69, 2001.

42. Sugiyama M, Bhawal UK, Dohmen T, Ono S, Miyauchi M and Ishikawa T: Detection of human papillomavirus-16 and HPV-18 DNA in normal, dysplastic, and malignant oral epithelium. Oral Surg Oral Med Oral Pathol Oral Radiol Endod 95: 594-600, 2003.

43. Zhang ZY, Sdek P, Cao J and Chen WT: Human papillomavirus type 16 and 18 DNA in oral squamous cell carcinoma and normal mucosa. Int J Oral Maxillofac Surg 33: 71-74, 2004.

44. Ostwald C, Muller P, Barten M, Rutsatz K, Sonnenburg M, Milde-Langosch K and Loning T: Human papillomavirus DNA in oral squamous cell carcinomas and normal mucosa. J Oral Pathol Med 23: 220-225, 1994. 
45. Park NH, Min BM, Li SL, Huang MZ, Cherick HM and Doniger J: Immortalization of normal human oral keratinocytes with type 16 human papillomavirus. Carcinogenesis 12: 1627-1631, 1991.

46. Czegledy J, Gergely L, Hernadi Z and Poka R: Detection of Papillomavirus DNA in the lower female genital tract. Orv Hetil 129: 1637-1640, 1988.

47. Havre PA, Yuan J, Hedrick L, Cho KR and Glazer PM: p53 inactivation by HPV16 E6 results in increased mutagenesis in human cells. Cancer Res 55: 4420-4424, 1995.

48. Meng XJ: Correlation of human papilloma virus (HPV) and herpes simplex virus-2 (HSV-2)in the viral etiology of carcinoma of uterine cervix. Zhonghua Zhong Liu Za Zhi 11: 108-110, 1989.

49. Cavuslu S, Goodlad J, Hobbs C, Connor AM, Raju KS, Best JM and Cason J: Relationship between human papillomavirus infection and overexpression of p53 protein in cervical carcinomas and lymph node metastases. J Med Virol 53: 111-117, 1997.

50. Chua KL, Wiklund F, Lenner P, Angstrom T, Hallmans G, Bergman F, Sapp M, Schiller J, Wadell G, Hjerpe A and Dillner J: A prospective study on the risk of cervical intra-epithelial neoplasia among healthy subjects with serum antibodies to HPV compared with HPV DNA in cervical smears. Int J Cancer 68: 54-59, 1996.

51. Semczuk A, Stenzel A, Baranowski W, Rozynska K, Cybulski M, Kostuch M, Jakowicki J and Wojcierowski J: Detection of human papillomavirus types 16 and 18 in human neoplastic endometrium: lack of correlation with established prognostic factors. Oncol Rep 7: 905-910, 2000.

52. Vandepapeliere P, Barrasso R, Meijer CJ, Walboomers JM, Wettendorff M, Stanberry LR and Lacey CJ: Randomized controlled trial of an adjuvanted human papillomavirus (HPV) type 6 L2E7 vaccine: Infection of external anogenital warts with multiple HPV types and failure of therapeutic vaccination. J Infect Dis 192: 2099-2107, 2005.

53. zur Hausen H: Papillomaviruses and cancer: from basic studies to clinical application. Nat Rev Cancer 2: 342-350, 2002.

54. Syrjanen K, Syrjanen S, Lamberg M, Pyrhonen S and Nuutinen J: Morphological and immunohistochemical evidence suggesting human papillomavirus (HPV) involvement in oral squamous cell carcinogenesis. Int J Oral Surg 12: 418-424, 1983.

55. Thompson IO, van der Bijl P, van Wyk CW and van Eyk AD: A comparative light-microscopic, electron-microscopic and chemical study of human vaginal and buccal epithelium. Arch Oral Biol 46: 1091-1098, 2001.

56. Al-Bakkal G, Ficarra G, McNeill K, Eversole LR, Sterrantino G and Birek C: Human papilloma virus type 16 E6 gene expression in oral exophytic epithelial lesions as detected by in situ rtPCR. Oral Surg Oral Med Oral Pathol Oral Radiol Endod 87: 197-208, 1999.

57. Kim MS, Shin KH, Baek JH, Cherrick HM and Park NH: HPV-16, tobacco-specific N-nitrosamine, and N-methyl-N'nitro-N-nitrosoguanidine in oral carcinogenesis. Cancer Res 53: 4811-4816, 1993

58. Shin KH, Min BM, Cherrick HM and Park NH: Combined effects of human papillomavirus-18 and N-methyl-N'-nitro-Nnitrosoguanidine on the transformation of normal human oral keratinocytes. Mol Carcinog 9: 76-86, 1994.

59. Fouret P, Martin F, Flahault A and Saint-Guily JL: Human papillomavirus infection in the malignant and premalignant head and neck epithelium. Diagn Mol Pathol 4: 122-127, 1995.

60. Bouda M, Gorgoulis VG, Kastrinakis NG, Giannoudis A, Tsoli E, Danassi-Afentaki D, Foukas P, Kyroudi A, Laskaris G, Herrington CS and Kittas C: 'High risk' HPV types are frequently detected in potentially malignant and malignant oral lesions, but not in normal oral mucosa. Mod Pathol 13: 644-653, 2000.

61. FONTEC. Fonstdtedc: Le precancerosi orali. Protocollo di diagnosi e terapia, 1989.

62. Gassenmaier A: Papilloma virus DNA (HPV) in leukoplakial and cancerous alterations of the oral mucosa. Dtsch Z Mund Kiefer Gesichtschir 12: 149-151, 1988.

63. Gassenmaier A and Hornstein OP: Presence of human papilloma-virus DNA in benign and precancerous oral leukoplakias and squamous cell carcinomas. Dermatologica 176: 224-233, 1988.

64. Perrons C, Brink N, Jalal H, Watts P and Jelley R: The impact of high risk human papillomavirus testing in an inner London colposcopy clinic. J Med Virol 76: 576-582, 2005.
65. Palefsky JM, Silverman S Jr, Abdel-Salaam M, Daniels TE and Greenspan JS: Association between proliferative verrucous leukoplakia and infection with human papillomavirus type 16. J Oral Pathol Med 24: 193-197, 1995.

66. van der Waal I, Schepman KP, van der Meij EH and Smeele LE: Oral leukoplakia: a clinicopathological review. Oral Oncol 33: 291-301, 1997.

67. Sugerman PB, Savage NW, Walsh LJ, Zhao ZZ, Zhou XJ, Khan A, Seymour GJ and Bigby M: The pathogenesis of oral lichen planus. Crit Rev Oral Biol Med 13: 350-365, 2002.

68. Suarez P, Batsakis JG and el-Naggar AK: Leukoplakia: still a gallimaufry or is progress being made? - A review. Adv Anat Pathol 5: 137-155, 1998.

69. Fejerskov O, Roed-Petersen B and Pindborg JJ: Clinical, histological and ultrastructural features of a possibly virusinduced oral leukoplakia. Acta Pathol Microbiol Scand 85: 897-906, 1977.

70. Loning T, Ikenberg H, Becker J, Gissmann L, Hoepfer I and zur Hausen H: Analysis of oral papillomas, leukoplakias, and invasive carcinomas for human papillomavirus type related DNA. J Invest Dermatol 84: 417-420, 1985.

71. Kashima HK, Kutcher M, Kessis T, Levin LS, de Villiers EM and Shah K: Human papillomavirus in squamous cell carcinoma, leukoplakia, lichen planus, and clinically normal epithelium of the oral cavity. Ann Otol Rhinol Laryngol 99: 55-61, 1990

72. Shroyer KR and Greer RO Jr: Detection of human papillomavirus DNA by in situ DNA hybridization and polymerase chain reaction in premalignant and malignant oral lesions. Oral Surg Oral Med Oral Pathol 71: 708-713,1991.

73. Axell T, Pindborg JJ, Smith CJ and van der Waal I: Oral white lesions with special reference to precancerous and tobaccorelated lesions: conclusions of an international symposium held in Uppsala, Sweden, May 18-21 1994. International Collaborative Group on Oral White Lesions. J Oral Pathol Med 25: 49-54, 1996.

74. Campisi G, Di Fede O, Giovannelli L, Capra G, Greco I, Calvino F, Maria Florena A and Lo Muzio L: Use of fuzzy neural networks in modeling relationships of HPV infection with apoptotic and proliferation markers in potentially malignant oral lesions. Oral Oncol 41: 994-1004, 2005.

75. Hansen LS, Olson JA and Silverman S Jr: Proliferative verrucous leukoplakia. A long-term study of thirty patients. Oral Surg Oral Med Oral Pathol 60: 285-298, 1985.

76. Silverman S Jr and Gorsky M: Proliferative verrucous leukoplakia: a follow-up study of 54 cases. Oral Surg Oral Med Oral Pathol Oral Radiol Endod 84: 154-157, 1997.

77. Femiano F: Papilloma virus. Note I: identification and related oral pathology. Review of the literature. Minerva Stomatol 49: 281-292, 2000.

78. Fettig A, Pogrel MA, Silverman S Jr, Bramanti TE, Da Costa M and Regezi JA: Proliferative verrucous leukoplakia of the gingiva. Oral Surg Oral Med Oral Pathol Oral Radiol Endod 90: 723-730, 2000.

79. Cox M, Maitland N and Scully C: Human herpes simplex-1 and papillomavirus type 16 homologous DNA sequences in normal, potentially malignant and malignant oral mucosa. Eur J Cancer B Oral Oncol 29B: 215-219, 1993.

80. Sand L, Jalouli J, Larsson PA and Hirsch JM: Human papilloma viruses in oral lesions. Anticancer Res 20: 1183-1188, 2000.

81. Vesper M, Riethdorf S, Christoph E, Ruthke A, Schmelzle R and Loning T: Detection of human papillomavirus (HVP)-DNA in oral manifestation of lichen planus. Mund Kiefer Gesichtschir 1: 146-149, 1997.

82. Jontell M, Watts S, Wallstrom M, Levin L and Sloberg K: Human papilloma virus in erosive oral lichen planus. J Oral Pathol Med 19: 273-277, 1990.

83. Gonzalez-Moles MA, Rodriguez-Archilla A, Ruiz Avila I, Esteban F, Gonzalez-Moles S and Bravo M: Presence of HPV 16 sequences in oral lichen planus lesions. Bull Group Int Rech Sci Stomatol Odontol 40: 92-97, 1998

84. Ostwald C, Rutsatz K, Schweder J, Schmidt W, Gundlach K and Barten M: Human papillomavirus $6 / 11,16$ and 18 in oral carcinomas and benign oral lesions. Med Microbiol Immunol 192: 145-148, 2003

85. Girja KP, Sundharam BS, Krishnan PA and Devi CS: Biochemical changes of saliva in tobacco chewers, tobacco smokers, alcohol consumers, leukoplakia and oral cancer patients. Indian J Dent Res 13: 102-107, 2002. 
86.Daling JR, Madeleine MM, Johnson LG, Schwartz SM, Shera KA, Wurscher MA, Carter JJ, Porter PL, Galloway DA, McDougall JK and Krieger JN: Penile cancer: importance of circumcision, human papillomavirus and smoking in in situ and invasive disease. Int J Cancer 116: 606-616, 2005.

87. Pande P, Soni S, Kaur J, Agarwal S, Mathur M, Shukla NK and Ralhan R: Prognostic factors in betel and tobacco related oral cancer. Oral Oncol 38: 491-499, 2002.

88.Zavras AI, Douglass CW, Joshipura K, Wu T, Laskaris G, Petridou E, Dokianakis G, Segas J, Lefantzis D, Nomikos P, Wang YF and Diehl SR: Smoking and alcohol in the etiology of oral cancer: gender-specific risk profiles in the south of Greece. Oral Oncol 37: 28-35, 2001.

89. Scully C, Field JK and Tanzawa H: Genetic aberrations in oral or head and neck squamous cell carcinoma (SCCHN): 1. Carcinogen metabolism, DNA repair and cell cycle control. Oral Oncol 36: 256-263, 2000.

90. Cui BN, Xu X and Zhao YS: Clinical efficacy of compound periploca liquid in treating condyloma acuminatum and its effect on human papilloma virus DNA expression in vitro. Zhongguo Zhong Xi Yi Jie He Za Zhi 25: 392-396, 2005.

91.Johnson NW and Warnakulasuriya KA: Epidemiology and aetiology of oral cancer in the United Kingdom. Community Dent Health 10 (suppl 1): 13-29, 1993.

92. Bodaghi S, Wood LV, Roby G, Ryder C, Steinberg SM and Zheng ZM: Could human papillomaviruses be spread through blood? J Clin Microbiol 43: 5428-5434, 2005.

93.Zheng TZ, Boyle P, Hu HF, Duan J, Jian PJ, Ma DQ, Shui LP, Niu SR, Scully C and MacMahon B: Dentition, oral hygiene, and risk of oral cancer: a case-control study in Beijing, People's Republic of China. Cancer Causes Control 1: 235-241, 1990.

94. Reichart PA: Infections of the oral mucosa II. Bacterial, mycotic and viral infections. Mund Kiefer Gesichtschir 3: 298-308, 1999.

95. Talamini R, Vaccarella S, Barbone F, Tavani A, La Vecchia C, Herrero R, Munoz N and Franceschi S: Oral hygiene, dentition, sexual habits and risk of oral cancer. Br J Cancer 83: 1238-1242, 2000.

96. Boyle P, Macfarlane GJ, Blot WJ, Chiesa F, Lefebvre JL, Azul AM, de Vries N and Scully C: European School of Oncology Advisory report to the European Commission for the Europe Against Cancer Programme: oral carcinogenesis in Europe. Eur J Cancer B Oral Oncol 31B: 75-85, 1995.

97.La Vecchia C, Tavani A, Franceschi S, Levi F, Corrao G and Negri E: Epidemiology and prevention of oral cancer. Oral Oncol 33: 302-312, 1997.

98. Sugerman PB and Shillitoe EJ: The high risk human papillomaviruses and oral cancer: evidence for and against a causal relationship. Oral Dis 3: 130-147, 1997.

99. Balaram P, Nalinakumari KR, Abraham E, Balan A, Hareendran NK, Bernard HU and Chan SY: Human papillomaviruses in 91 oral cancers from Indian betel quid chewers - high prevalence and multiplicity of infections. Int J Cancer 61: 450-454, 1995.

100. Miller CS, Zeuss MS and White DK: Detection of HPV DNA in oral carcinoma using polymerase chain reaction together with in situ hybridization. Oral Surg Oral Med Oral Pathol 77: 480-486, 1994.

101. Ha PK and Califano JA: The role of human papillomavirus in oral carcinogenesis. Crit Rev Oral Biol Med 15: 188-196, 2004.

102.Paz IB, Cook N, Odom-Maryon T, Xie Y and Wilczynski SP: Human papillomavirus (HPV) in head and neck cancer. An association of HPV 16 with squamous cell carcinoma of Waldeyer's tonsillar ring. Cancer 79: 595-604, 1997.

103. Herrero R, Castellsague X, Pawlita M, Lissowska J, Kee F, Balaram P, Rajkumar T, Sridhar H, Rose B, Pintos J, Fernandez L, Idris A, Sanchez MJ, Nieto A, Talamini R, Tavani A, Bosch FX, Reidel U, Snijders PJ, Meijer CJ, Viscidi R, Munoz N and Franceschi S: Human papillomavirus and oral cancer: the International Agency for Research on Cancer multicenter study. J Natl Cancer Inst 95: 1772-1783, 2003.

104. Mork J, Lie AK, Glattre E, Hallmans G, Jellum E, Koskela P, Moller B, Pukkala E, Schiller JT, Youngman L, Lehtinen M and Dillner J: Human papillomavirus infection as a risk factor for squamous-cell carcinoma of the head and neck. N Engl J Med 344: 1125-1131, 2001

105. Fleming ID, Cooper JS, et al: AJCC cancer staging manual. 5th edition. Lippincott-Raven, Philadelphia, 1997.
106. Kreimer AR, Clifford GM, Boyle P and Franceschi S: Human papillomavirus types in head and neck squamous cell carcinomas worldwide: a systematic review. Cancer Epidemiol Biomarkers Prev 14: 467-475, 2005.

107. Boring CC, Squires TS, Tong T and Montgomery S: Cancer statistics, 1994. CA Cancer J Clin 44: 7-26, 1994.

108. Hafkamp HC, Speel EJ, Haesevoets A, Bot FJ, Dinjens WN, Ramaekers FC, Hopman AH and Manni JJ: A subset of head and neck squamous cell carcinomas exhibits integration of HPV 16/18 DNA and overexpression of p16INK4A and p53 in the absence of mutations in p53 exons 5-8. Int J Cancer 107: 394-400, 2003

109.Smith EM, Ritchie JM, Summersgill KF, Hoffman HT, Wang DH, Haugen TH and Turek LP: Human papillomavirus in oral exfoliated cells and risk of head and neck cancer. J Natl Cancer Inst 96: 449-455, 2004.

110. Lo Muzio L, D'Angelo M, Procaccini M, Bambini F, Calvino F, Florena AM, Franco V, Giovannelli L, Ammatuna P and Campisi G: Expression of cell cycle markers and human papillomavirus infection in oral squamous cell carcinoma: use of fuzzy neural networks. Int J Cancer 115: 717-723, 2005.

111. Schwartz SM, Daling JR, Doody DR, Wipf GC, Carter JJ, Madeleine MM, Mao EJ, Fitzgibbons ED, Huang S, Beckmann AM, McDougall JK and Galloway DA: Oral cancer risk in relation to sexual history and evidence of human papillomavirus infection. J Natl Cancer Inst 90: 1626-1636, 1998.

112.Chang JY, Lin MC and Chiang CP: High-risk human papillomaviruses may have an important role in non-oral habits-associated oral squamous cell carcinomas in Taiwan. Am J Clin Pathol 120: 909-916, 2003.

113. Dahlstrom KR, Adler-Storthz K, Etzel CJ, Liu Z, Dillon L, El-Naggar AK, Spitz MR, Schiller JT, Wei Q and Sturgis EM: Human papillomavirus type 16 infection and squamous cell carcinoma of the head and neck in never-smokers: a matched pair analysis. Clin Cancer Res 9: 2620-2626, 2003.

114. Ritchie JM, Smith EM, Summersgill KF, Hoffman HT, Wang D, Klussmann JP, Turek LP and Haugen TH: Human papillomavirus infection as a prognostic factor in carcinomas of the oral cavity and oropharynx. Int J Cancer 104: 336-344, 2003.

115.Dai M, Clifford GM, le Calvez F, Castellsague X, Snijders PJ, Pawlita M, Herrero R, Hainaut P and Franceschi S: Human papillomavirus type 16 and TP53 mutation in oral cancer: matched analysis of the IARC multicenter study. Cancer Res 64: 468-471, 2004.

116. Azzimonti B, Pagano M, Mondini M, De Andrea M, Valente G, Monga G, Tommasino M, Aluffi P, Landolfo S and Gariglio M: Altered patterns of the interferon-inducible gene IFI16 expression in head and neck squamous cell carcinoma: immunohistochemical study including correlation with retinoblastoma protein, human papillomavirus infection and proliferation index. Histopathology 45: 560-572, 2004.

117. Akerman GS, Tolleson WH, Brown KL, Zyzak LL, Mourateva E, Engin TS, Basaraba A, Coker AL, Creek KE and Pirisi L: Human papillomavirus type 16 E6 and E7 cooperate to increase epidermal growth factor receptor (EGFR) mRNA levels, overcoming mechanisms by which excessive EGFR signaling shortens the life span of normal human keratinocytes. Cancer Res 61: 3837-3843, 2001.

118. Ringstrom E, Peters E, Hasegawa M, Posner M, Liu M and Kelsey KT: Human papillomavirus type 16 and squamous cell carcinoma of the head and neck. Clin Cancer Res 8: 3187-3192, 2002.

119. Gillison ML, Koch WM, Capone RB, Spafford M, Westra WH, Wu L, Zahurak ML, Daniel RW, Viglione M, Symer DE, Shah KV and Sidransky D: Evidence for a causal association between human papillomavirus and a subset of head and neck cancers. J Natl Cancer Inst 92: 709-720, 2000.

120. Snijders PJ, Scholes AG, Hart CA, Jones AS, Vaughan ED, Woolgar JA, Meijer CJ, Walboomers JM and Field JK: Prevalence of mucosotropic human papillomaviruses in squamous-cell carcinoma of the head and neck. Int J Cancer 66: 464-469, 1996

121.Higa M, Kinjo T, Kamiyama K, Chinen K, Iwamasa T, Arasaki A and Sunakawa H: Epstein-Barr virus (EBV)-related oral squamous cell carcinoma in Okinawa, a subtropical island, in southern Japan - simultaneously infected with human papillomavirus (HPV). Oral Oncol 39: 405-414, 2003. 
122. Correnti M, Rivera H and Cavazza ME: Detection of human papillomaviruses of high oncogenic potential in oral squamous cell carcinoma in a Venezuelan population. Oral Dis 10: 163-166, 2004.

123. Schwartz SR, Yueh B, McDougall JK, Daling JR and Schwartz SM: Human papillomavirus infection and survival in oral squamous cell cancer: a population-based study. Otolaryngol Head Neck Surg 125: 1-9, 2001.
124. Campisi G, Giovannelli L, Calvino F, Matranga D, Colella G, Di Liberto C, Capra G, Leao JC, Lo Muzio L, Capogreco M and D'Angelo M: HPV infection in relation to OSCC histological grading and TNM stage. Evaluation by traditional statistics and fuzzy logic model. Oral Oncol 42: 638-645, 2006. 